\title{
Praise of Heart on Hahslm in Covid-19 and Economic
}

\author{
$1^{\text {st }} \mathrm{R}$ Mochamad A \\ Universitas Islam Negeri Syarif \\ Hidayatullah Jakarta \\ Jakarta, Indonesia \\ r.mochamada@gmail.com
}

\begin{abstract}
There are various aspects of human life in the medical field about the heart such as the circulatory system of heart and heart rate machine with religiosity factor. This research aims to analyze the relationships among medical in the human body, circular system of heart, and religiosity of heart. Data gets from various sources books, journals, internet, primary data, and secondary data also from the holy book. Primary data gets from electrocardiogram (ECG) with the rate of the heart. The methodology used in this study is the approach of hahslm with main variables from religiosity aspects and internal-external factors of medical. The methods are similarity and reflexivity based on hahslm method. The similarity between ECG and the form of SLM symbols. Reflexivity in the main variables of heart rate. The results are human heart always praises Allah and the graph of heart rate in ECG shows the symbols of a sequence of prayers order. Heart praises to God with a sentence of Glorious, Merciful, Sustain, and Cycle. Covid-19 influences the heart system with an effect onthe macro environment of economic.
\end{abstract}

Keywords - hahslm, heart, praise, COVID-19, ECG, economic

\section{INTRODUCTION}

\section{A. Background}

The advancement of medical science today seems to have forgotten the contribution of religious texts, which is the Qur'an and the Hadith. As we know, progress in the 20th century alone has resulted in a large literature and understanding of anatomy, drug health, and the correlation between the two.

By times, each generation has a higher level of civilization compared to the previous generation. At each level of human civilization, there are only natural secrets that open the veil. This is because human nature itself is always curious and continue to think to seek answers to various things that exist in this world. But on the other hand, there is also an undeniable fact that there is a destiny there that belongs to the creator of nature, and becomes the secret of the power that determines the time, when it is time to unfold the secret of the creation of the universe for the benefit of man.

Humanity by the level of civilization in every decade has an increasingly good ability to unveil the secret of the existence of the entire universe in this universe. The more open the veil, the more the world is amazed at the Islamic message. Because so many secrets are perfectly summarized by the message of Islam in the revelation of Allah SWT, AlQur'an and the words and actions of the Prophet Muhammad, and as-Sunnah.

The essay must be a benchmark in human life. Because it is a guide for man, then the content of the treatise is the way of human life according to his nature. These guidelines can be reached by humans if humans are indeed thinking and trying to find the truth. The Islamic treatise sourced from the Qur'an will be preserved by Allah SWT forever, along with his word:

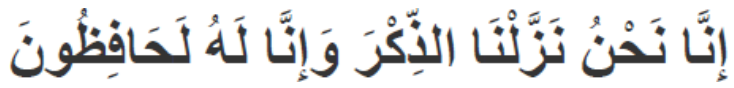

"It is We who sent down the Qur'an and indeed, we take care of it". (QS. Al-Hijr [15]: 9)

Islamic treatise is a treatise that stands on the objective reality of man with the nature possessed by man. Therefore humans are required to have the ability to reveal the wisdom of Islamic treatises contained in the Qur'an or as-Sunnah.

The Qur'an and hadith are the guidance of man. In it, there are clues about various aspects of human life, including the medical field, especially about the heart, the circulatory system, the circulatory system, and many other things, which will be a special discussion on this paper. In the Qur'an and hadith, we can find accurate depictions of anatomical structure, physiology, medicine, prevention, and spiritual health. It is said that COVID- 19 can cause heart injury even for those who have no history of this disease. This pandemic in the global situation affects the environment of the economic [1].

\section{B. Problem Formulation}

What is the relationship between heart and Islam in Electrocardiogram om Hahslm theory?

\section{Purpose}

To analyze the relationship between heart and Islam in Electrocardiogram on Hahslm theory.

\section{Benefits}

Able to be a reference for Lecturers, Students, and academics who will research Heart and Religion to have integration between science and Islam based on Muslim methodology. 


\section{THEORETICAL BASIS}

\section{A. Islam Kaffah}

Islam rahmatan lilalamin is an integral part of a core part of the living system that exists in man, in the environment, and the universe which means that all life begins from the concept of Islam kaffah. In other words, the earliest creation process was Islam [2].

Islam Kaffah, which has been comprehensive in all its aspects, is Islam that has been accepted by the Companions directly from Rasulullah SAW and they do under the supervision of SAW, even direct divine praise. If something is not right or wrong, then down verse reminds of an event, or down verses again detailing the problem. The direct supervision of the seventh heaven, ie the direct supervision of Allah SWT which decreases this shari'ah. Therefore, the Prophet sallallaahu 'alaihiwasallam said: "The best of generations is the generation in which I am there." What does it mean best in what way? In all matters of religion, morality is the best of the Sahaba, his faith is also the best. Worship, both the quality level and the quantity level, the shahadat are the best. Because the Messenger of Allah (peace and blessings of Allah be upon him) firmly declares that the generation is the generation where I am.

According to the theory developed by Aziz [3] on the theory of Hahslm about the development of epistemology in the research of a comprehensive system with approach method according to Arabic rule that is to see the word Islamin basic word format consisting of 3 consonant letter, that is Sin, lam, mim. It is then formulated in the function of an Islamic formula called $\mathrm{H}$ theory, always based on its basic philosophy, consisting of ontology in Islam, epistemology in kaffah, and its axiomatic patterned stance in the form of warning and kindness, so it is stated that the emergence of Islam, forming the concept of kaffah, Which is done through warning and kindness. This is by the contents of the Qur'an which reads "silmikaffah" with the word "silmi" which is a derivation of the letters sin lam mim.

The formulation of the three basic philosophical elements of Islam is in sync with the approach that produces the $\mathrm{H}$ theory which is the elaboration of the basic word of Islam itself [3]. Islamic scholarship must have a foundation of thought, as a theory to be implemented in the field by the progress of science at this time. It takes synchronization between the theory derived from the Quran with the practices that occur in the simulation and modern technology, so it takes a corridor of a big concept of the basic science of Islam itself. Islamic science comes from monotheism and stops at monotheism as well.

\section{B. Ontology}

The Islamic ontology is monism, meaning that God is the origin of all things, the One and there are no allies to Him, while all of His creations are dualism and pluralism.

Each whole concept must have a consistent rationale. In general knowledge, a concept that is always consistent in its true will become a universal form that is understood as the basic value which will be possessed by another form.

Ontologically all creation or creation or universe is a system and the basic system is called Islam. Based on this system, the subsystems present in the universe will be consistent with the basic system. Throughout the elements of the system. Surah Al-Imran [3]: 19:

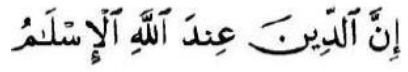

"Indeed Din Allah is Islam" (QS.Al Imran [3]: 19)

\section{Epistimology}

Epistemology is a study of science that is very popular and become the most interesting thing. Simply Epistemology is a subject that examines the knowledge and its relation to the essential truth. Epistemology becomes an interesting discussion when it is associated with divinity because the ultimate truth will only be possessed by God, therefore the essence of the ultimate truth that is subject to Epistemology becomes impossible to obtain by the thought and taste of man as a creature of God [4].

Islamic epistemology is eclectic, not only rational, empirical but also intuitive and based on revelation as the first and main source. Islam is interpreted as a holistic system, comprehensive or wholly. Then it is the whole Islam that becomes epistemology and is called the kaffah concept of Islam [5].

Surah Al-Baqarah [2] 208:

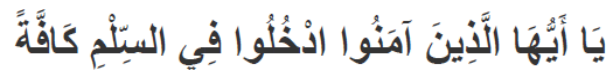

"O ye who believe! Enter into Islam you kaffah (complete)." (QS. Al-Baqarah [2]: 208).

\section{Axiology}

The axiom aspect of philosophy discusses the values or morals prevailing in human life. Previously there was a discussion of ontology which means Islam and then epistemology as the kaffah of an existing system and the axiology of the simple implementation of the two previous elements is Ontology and epistemology [6].

In this axiology, there are always two relationships between horizontal and vertical structures. The emergence of Islam, forming the concept of Kaffah, which has two sides side by side in nature. These two things are analogized as different things like men and women, light and dark. As per QS. Yasin [36]: 36 which states two things:

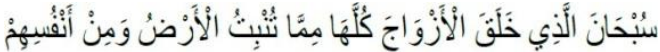

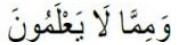

"Glory be to God Who created all the pairs, whether from what the earth grows and from themselves and from what they do not know" (Surah Yasin 36:36)

\section{E. Heart}

The heart is a strong muscle that pumps blood throughout the body in a coordinated way of contraction [7]. The heart (Latin, cast) is a muscular organ cavity that pumps blood through a blood vessel by repeated rhythmic contractions. Heart means ingredients related to the heart, from the Greek word cardia to the heart. The heart is one of the organs of the human body that plays a role in the circulatory system [8]. 
The heart is located in the cest cavity. The size of the heart is about the size of a fist weighing about 300 grams. The heart in the circulatory system serves as a blood pump.

The heart consists of heart muscle (myocardium). The outer cardiac membrane part is coated with a cardiac membrane (pericardium). The pericardium consists of 2 layers. The outer layer is called the lamina panistalis and the inner layer attached to the heart wall is called the visceral lamina. Between these layers, there is a space of pericardial cavity filled with pericardial fluid. This fluid serves to resist friction. The inside is coated with the endocardium.

The work of the heart through repetitive and continuous mechanisms also known as the heart cycle so that it visually sees or is known as the heart rate. Through intermittent mechanisms, the heart proceeds to empty the contents of the heart and relax to fill with blood. In the cycle, do the systolic heart period is the period when the contract and empty the contents (blood), and the period of diastolic is the period of relaxation and fill in go blood to the heart. Both loosened the terrace and contract simultaneously, and both booths also relaxed and the contracts simultaneously also carried out the mechanism [9].

In general, the main heart function is to pump blood throughout the body and hold it back after cleaning the lungs organ. This means that the function of the human heart is a tool or organ pumping blood in humans. At that time the heart provides enough blood oxygen and flowed throughout the body, and cleanses the body of the metabolic (carbon dioxide) product. So, to carry out this function the heart collects oxygen-deficient blood all over the body and then pumps it into the lungs, using the blood in the heart to take oxygen and dispose of carbon dioxide. At the heart of oxygen-rich blood coming from the lungs is pumped in to the this isues of theentire human body.

\section{METHOD}

\section{A. HahslmMethod}

The Hahslm method is a genuine method of Islam because Derived from Quran Surah Al-Hijr (15): 87.

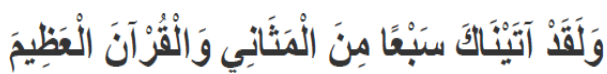

"And we have given you seven verses over and over and the great Qur'an" (QS. Al-Hijr [15]: 87) [10].

Formula: $\mathrm{H}=\mathrm{a} . \mathrm{h}$ (s.l.m)

Where: $\mathrm{H}=$ Huda (Heart System), $\mathrm{A}=$ Alif (Blood), $\mathrm{H}=$ Hanif (Flow of Blood), $\mathrm{S}=$ Sin (Aorta), L = Lilah (Heart), $M$ $=$ Mosque $($ Vena $)$

\section{B. The scope of research}

The scope of this study is to analyze the existence of heart praise in Electrocardiogram in the Islamic perspective according to $\mathrm{H}$ Theory in the Covid-19 disease with turbulence economic. This research is a qualitative research that analyzes data. The data sourced from tools of Electrocardiogram (ECG), journals, newspapers/magazines, television broadcasts, articles, or news. The study was conducted in the period from 2019 to 2020 .

\section{Method of collecting data}

Using the documentation method collects information and data through the method of library study, exploration of literature, and reports or sources derived from articles published by researchers. As well as a quantitative method. Secondary data needed in this study are as follows: journal and article about heart, ECG, Quran, Covid-19, adn Economic.

\section{Data Analysis}

There are clues about various aspects of human life, including the medical field. An explanation of the heart, blood, circulatory system, and others. Moreover, it was explained in Islam how to make a good and healthy lifestyle, so that it can live long, prevent the arrival of cardiovascular disease and prevent the risk of being exposed to the history of the disease. This discovery was very difficult to find by Western scientists, therefore the contribution of Islam is very large in the world of medicine and must always be remembered not to be forgotten.

\section{DISCUSSION}

\section{A. Heart And Islam}

After the text edit has been completed, the paper is ready for the template. Duplicate the template file by using the Save As command, and use the naming convention prescribed by your conference for the name of your paper. In this newly created file, highlight all of the contents and import your prepared text file. You are now ready to style your paper; use the scroll down window on the left of the MS Word Formatting toolbar.

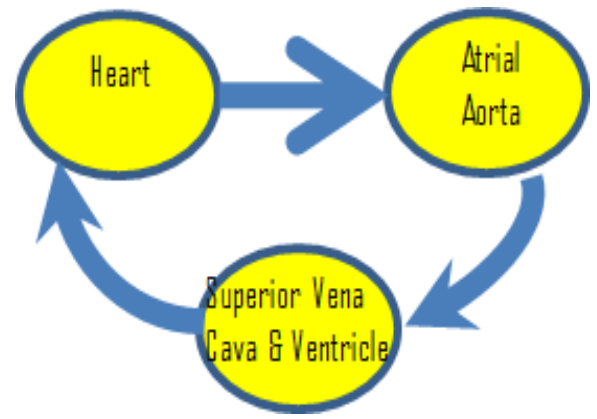

Fig. 1. Heart Thinking, source: Analysis 2020

A study of heart and cardiovascular showed that there was a connection between Quran as a holy book in Islam with the heart system and cardiovascular and did not mention the graph of heart pulse that shows in the Electrocardiogram (ECG) [11] . This study makes three-part of heart pulse with the terminology of sin, lam, and mim. In this research, the heart as the core organ of the human is denoted as (lam) instructions. Because the function of the heart itself is very important that is to pump blood. Then in the heart, there is a section called Aorta. This aorta serves to carry blood containing oxygen. This aorta is represented as (sin) because it functions as a blood-carrying carrier containing oxygen to some other part of the heart such as the lungs, left ventricle, and the right chamber before passing through the body. The atrium itself is usually referred to as a porch, where there are two parts of the left porch and the right porch. 
The function of the left foyer brings blood to the left ventricle or also called the left ventricle and the right porch serves to carry oxygen-rich blood to the right ventricle or also called the right chamber. Then the last one on the heart is the superior vena cava \& ventricles. These two parts are in the same place, which is located on the left side of the heart that serves to receive blood flow from the aorta earlier. This part of the ventricle is also called the cubicle. This chamber was divided into two parts namely the left chamber and the right chamber. The function of each room is different. The right chamber serves blood from the right atrium (the right side) and then spreads to the lungs, then the left ventricle receives blood from the left atrium (left portico) and carries it throughout the body. Then after the left ventricle to flow throughout the body, this is where the superior vena cava function is to bring blood that contains carbon dioxide back into the heart so that the heart can receive blood in-take and continue in the pump again as in the picture above. Thus the superior vena cava and Ventricle are represented as (mim).

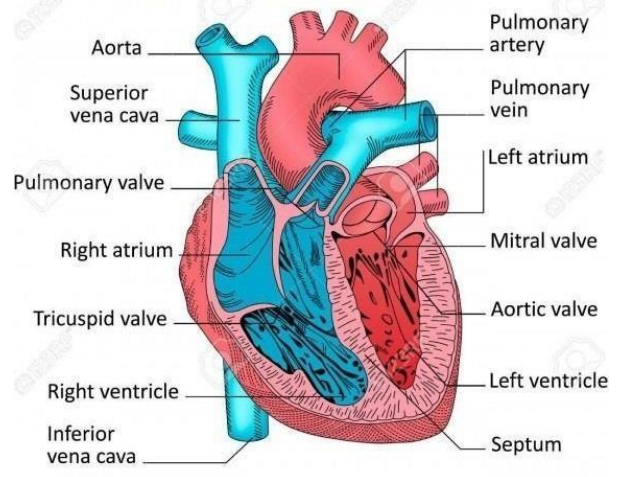

Fig. 2. Heart Anatomy [12]

The picture above explains the flow of the human circulatory system at the core of the heart line. The heart as the central core of the human organs, where the blood is in the heart (lam) in the pump / channeled to the right called aorta ( $\sin )$, where this aorta has a primary function to direct blood flow to the whole body, but before that, flowed the first go to the left atrium (left porch). The main function of the left porch is to receive the blood that is rich in oxygen and then redirected back to the left ventricle (left chamber). After the left chamber receives blood from the left foyer is the main function of the left chamber to drain the blood throughout the body or commonly called "big blood circulation". However, several blood streams are flowing into the Vava Superior (VKS) section, where the function of this $\mathrm{VKF}$ redirects blood to the heart.

Then for the right atrium (right porch) serves to receive blood rich in carbon dioxide and then circulated to the right ventricle (right ventricle). Then this is where the function of the right ventricle (right ventricle) is to drain the blood to the lungs or commonly called the "small blood circulation". Such is the description of the analysis of the picture above, that the blood circulation in the human heart has been in a very neat and structured arrangement. It all happened Because of the power of Allah SWT. By the concept of Hahslm, our heart can function optimally with the aim that we can perform daily life activities and most importantly we are created by Allah SWT to worship Him.

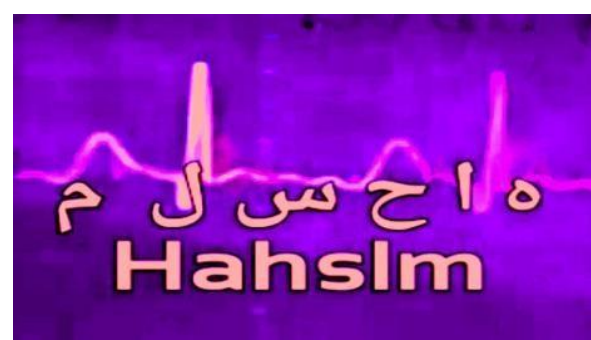

Fig. 3. Heart Praise [13]

According to the chart that is observed in the Electrocardiogram (ECG) monitor, each heartbeat can be divided into three (3) phases. The first phase is a range of preparation of the heart for pulsing. In this initial phase, blood flow is headed towards the heart and almost flow in the heart. In this first phase, it has been seen the signs of a heart a right under pressure the presence of the initial pressure although light but fast sequential. The analogy of this blood flow to the heart is like a basketball that is dribbled with resulting in a graph of up and down thick and fast. As a result of the ball being reflected on the floor by hand.

The shape of the graph up and down, thick and many of these as well as sign of arrival a massive tsunami or signs of a large earthquake. By the methodology of similarity, graphic patterns of up and down or thick and many resemble the letter S or the letter Sin in Hijiyah or approaching number 3 (three) which means plural or many in Arabic structure. This interpretation of thick and many is compassionate and fostered because groups of small but and many are more closely served with words of compassionand foster care. In religious terminology, referred to as the Glorious and Merciful whereas according to the Asmaul Husna that is known as Ar-Rahman Ar-Rahim.

In the second phase, it means occurred of a heartbeat. The highest pressure occurs in comparison with another phase. The ECG graph showing the vertical line, up to the extreme high and low indicating blood flow that was flowing the heart. The shape of high and low in this graph can be analogous to basketball that is connected to the top to be able to pass the opponent then enter the ring. By the methodology of similarity, this high graphic pattern resembles the letter L or Lam in Hijaiyah in the Arabic structure. Interpretation of the heart praise in this second phase is the heart does prayer movement know as rukuk that is long with a recitation of the Al-Azhim is defined as long, tall, or summarized into words sustain or become phrases Supreme Sustain.

Phase- 3 is a continuation of the main heart rate so that it can be categorized as residual pressure results or result of cardiac stress. The graph on the ECG shows a line that is curved in a medium, not too big convex, nor too small concave. This semicircular shape showing the flow of blood which is leaving the heart. This curved shape can be analogous to basketball that is reflected after the occurrence of the high ball before. By the methodology of similarity, the semicircular lines resemble the letter M or Mim in Hijayah on the structure of Arabic. The interpretation of the heart in the 3rd phase is that the heart is performing the prayer movement which is prostration that is curved with the reading of Al-A'la. As bound as the circular or the Supreme Cycle. 
According to research by the China Centers for Disease Control and Prevention (CDC), the mortality rate for COVID-19 patients with heart disease in mainland China on December 30 and February 11 was 10.5 percent. Then the JAMA Cardiology study also concluded that heart injuries are common in hospitalized patients in China. The study was conducted from January to February using data from 416 adult patients who had a coronavirus infection, Covid-19. These patients are treated at Renmin Hospital in Wuhan University, China. And certainly related to the cost of treatment of patients with a history of heart disease or other diseases is very expensive because of the number of equipment and treatment that will be done in dealing with these patients [14].

There were 16-year- old male patients complaining of chest pain and mild fever and without flu symptoms. Electrocardiogram (ECG) heart record shows a picture resembling a heart attack. The positive Covid-19 swab test turned out to cause inflammation of the heart muscle. Although in the end the patient survives and returns on the 12th day. The patient is young not around 50 years old [15]. The results of operations by these doctors Corona Virus affect the heart rhythm. When the electro cardiogram shows a pattern like a patient having a heart attack, and the heart surgeon tries to open a blockage in the artery, nothing turns out to be blocking. Apparently because of the Corona Virus.

The heart condition is approaching STEMI (ST-segment Elevation Myocardial Infarction) is a type of damage to the heart that causes abnormalities typical of the results of an examination of the heart record. Inflammation by Corona Virus in any organ is predicted to leave irreversible fibrotic tissue. Meaning that his patient could not recover $100 \%$ with a history of heart disease.

At the New York Darutar Station, based on the explanation of the attending physician in New York, there were found many COVID patients with cardiovascular symptoms.

Research needs to be done there are patients who already have heart disease first, and heart disease becomes a concomitant disease. ECG data is needed before and after Covid-19 exposure. Because inflammation of the heart muscle has characteristic symptoms, the heart is rather attracted. A left chest as if someone is pressing. As a result of inflammation of the muscles while breathing it feels painful.

The information has been recorded that there are several symptoms of COVID that resemble a cardiovascular disease. There is inflammation of the heart muscle and some are in the form of blockage of vessels to the heart [16].

\section{CONCLUSION}

The heart is the most vital human organ because, with heart, the human can live in daily activities. In harmony with the Islamic religion, the heart is the organ that first formed, which serves to pump blood and drain it throughout the body, as well as the existence of Islamic religion. Islamic the religion that was first established since the first time of a human being created and sent down to earth.

From the 1,2,3 phase when the heart is beating from the ECG device a graph of heart pressure is displayed with the interpretation that the heart glorifies by performing prayer movements in the form of horizontal lines (S), vertical (L), and diagonal (M) which is interpreted by reading ArRahman Ar-Rahim, Al-Azhim, Al-A'la.

In the pandemic of Covid-19, the risk of heart disease can be higher than before. This environment with social distance, quarantine and isolation cause of the economic crisis in the global system. The heart is the most important organ and must be maintained by every human being to stay in a healthy and stable condition, as well as with Islam. Islam is the spiritual heart for Muslims that we should keep and always be used as a guide for life, to get physical and mental happiness.

\section{REFERENCES}

[1] C. Bavishi, T. M. Maddox, \& F.H. Messerli, "Coronavirus Disease 2019 (COVID-19) Infection and Renin Angiotensin System Blockers," In JAMA Cardiology, 2020. https://doi.org/10.1001/jamacardio.2020.1282

[2] R. Dogan, "The Position of Human Being in The Universe according to Islam," Sociology and Anthropology, 2013.

[3] R. M. Aziz, "Teori H dalam Islam Sebagai Wahyu dan Turats," Jurnal Ushuluddin, Volume 24, 2016. http://ejournal.uinsuska.ac.id/index.php/ushuludin

[4] A. Dahlan, "Hakikat dan pengertian epistemology dalam kajian filsafat ilmu," 2014.

[5] R. Arjmand, "Islamic Education: Historical Perspective, Origin and Foundation," 2017. https://doi.org/10.1007/978-3-319-53620-0_3-1

[6] R. M. Aziz, "New Paradigm On Sinlammim Kafah In Islamic Economics," Signifikan: Jurnal Ilmu Ekonomi 2012. https://doi.org/10.15408/sjie.v1i2.2604

[7] Fenton, H. Flavio and M. Elizabeth, "Heart Structure, Function and Arrhythmias," Cornell University, Ithaca, NY, 2012.

[8] H. Harun, and T. MA, "Fungsi Organ Tubuh Dari Sisi Medis Dan Al-Qur'an. Inspirasi," 2011.

[9] Yayasan Jantung Indonesia, "Fungsi Jantung Dalam Tubuh Manusia,” Yayasan Jantung Indonesia, YJI Socmed Team, 2015.

[10] Kementerian Agama, "Qur'an Kemenag," Lajnah Pentashihan Mushaf Al-Qur'an, 2020

[11] M. Loukas Y. Saad, R. S. Tubbs, and M. M. Shoja, "The heart and cardiovascular system in the Qur'an and Hadeeth," In International Journal of Cardiology. 2010. https://doi.org/10.1016/j.ijcard.2009.05.011

[12] B. Gall, W. Parkhouse, and D. Goodman, "Heart rate variabilty of recently concussed athletes at rest and exercise," Medicine and Science in Sports and Exercise, 2014. https://doi.org/10.1249/01.MSS.0000135787. 73757.4 
[13] R. M. Aziz, "Rumus Tuhan Hahslm Dalam Berpikir Menyeluruh Sebagai Metodologi Ekonomi Islam," Issue August, 2015.

[14] W. Qiu, C. Chu, A. Mao, and J. Wu, "The impacts on health, society, and economy of SARS and H7N9 Outbreaks in China: A Case Comparison Study," Journal of Environmental and Public Health, 2018. https://doi.org/10.1155/2018/2710185

[15] M. Gnecchi, F. Moretti, E. M. Bassi, S. Leonardi, R. Totaro, L. Perotti, V. Zuccaro, S. Perlini, L. Preda, F. Baldanti, R. Bruno, and L. O. Visconti, "Myocarditis in a 16-year-old boy positive for SARS-CoV-2," In The Lancet, 2020. https://doi.org/10.1016/S01406736(20)31307-6

[16] E. Ammirati, D.W. Wang, "SARS-CoV-2 inflames the heart. The importance of awareness of myocardial injury in COVID-19 patients," In International
Journal of Cardiology, 2020. https://doi.org/10.1016/j.ijcard.2020.03.086 